\title{
Relation of residual renal function and peritoneal transport rates with arterial stiffness in peritoneal dialysis patients
}

\section{Periton diyaliz hastalarında rezidüel renal fonksiyon ve peritoneal transport hızının arteriyel sertlikle ilişkisi}

\author{
Melahat ÇOBAN, Ayça İNCi \\ Antalya Ĕ̆itim ve Araştırma Hastanesi, Nefroloji Kliniği, Antalya, Türkiye
}

\begin{abstract}
Objective: It has been known that residual renal function (RRF) is preserved better in patients undergoing PD (peritoneal dialysis) therapy compared to HD patients. According to previous studies, in patients with high peritoneal transport rate (H-PTR) and decreased RRF, increased rates of cardiovascular $(\mathrm{CV})$ morbidity and mortality have been demonstrated. The aim of this study is to identify the relationship between RRF and PTRs with arterial stiffness (AS) in PD patients.

Methods: Seventy-five PD patients with a mean age of $53.7 \pm 13.3$ years were included in this cross-sectional study. AS was determined by the measurement of brachial-ankle pulse wave velocity (baPWV). Patients were divided into two subgroups according to median baPWV and rGFR values. Multivariate analysis was performed to determine independent factors affecting rGFR and PTRs.

Results: Fifty-six (74.6\%) patients were treated by continuous ambulatory peritoneal dialysis (CAPD). According to PET, $48(64 \%)$ patients had increased peritoneal permeability (H/ HA-PTR). Compared with low baPWV $(\leq 8.0 \mathrm{~m} / \mathrm{sec})$ group, older age $(\mathrm{p}=0.000)$, systolic blood pressure (SBP) $(p=0.000)$ and PD modality $(p=0.002)$ were significantly higher in high baPWV $(>8.0 \mathrm{~m} / \mathrm{sec}$ ) group. BaPWV, PTRs and PD modality were not different between the two groups (for all $p>0.05$ ). Age, rGFR,PD modality and baPWV were statistically similar between H-PTR and L-PTR groups (all $p>0.05$ ). In multivariate linear regression analysis; baPWV was independently associated with age $(p=0.001)$ and $\operatorname{SBP}(p=0.001)$. In multivariate linear regression analysis; there was no relationship between rGFR and baPWV ( $\mathrm{p}=0.751)$.

Conclusion: The rate of development of AS was similar between H-PTR and L-PTR groups. There was no independent relationship between rGFR and PTRs with AS in PD patients.
\end{abstract}

Keywords: Peritoneal, dialysis, arterial, stiffness

$\ddot{\mathbf{O Z Z}}$

Amaç: Hemodiyaliz (HD) hastalarına göre periton diyalizi (PD) hastalarında rezidüel renal fonksiyonun (RRF) daha iyi korunduğu bilinmektedir. Daha önceki çalışmalarda, yüksek peritoneal geçirgenlik (H-PTR) ve azalmış RRF olanlarda armış kardiyovasküler (CV) morbidite ve mortalite gösterilmiştir. Bu çalışmadaki amacımız, PD hastalarında RRF ve peritoneal transport hızları ile arteriyel sertlik (AS) arasındaki ilişkinin gösterilmesidir.

Yöntem: Bu kesitsel çalışmaya ortalama yaşı $53,7 \pm 13,3$ olan 75 PD hastası dahil edilmiştir. AS brakiyal arter nabız dalga hızı (baPWV) ölçülerek saptanmıştır. Hastalar ortalama baPWV ve residual glomerüler filtrasyon hızına (rGFR) göre iki gruba ayrılmışlardır. rGFR ve PTR etkileyen faktörleri saptamak için multivariate analiz yapılmıştır.

Bulgular: Elli altı $(\% 74,6)$ hasta sürekli ambulatuar periton diyalizi (CAPD) tedavisi yaparken, 48 (\%64) hastanın peritoneal geçirgenlik hızı yüksekti (H/HA-PTR). Düşük baPWV $(\leq 8,0 \mathrm{~m} /$ sec) gruba göre yüksek, baPWV (> 8,0 m/sec) grup; daha yaşlı $(\mathrm{p}=0,000)$, sistolik kan basıncı yüksektir (SBP) $(p=0,000)$. İki grupta baPWV, PTR ve PD modalitesi açısından fark saptanmadı $(p>0,05)$. Yaş, rGFR,PD modalitesi ve baPWV açısından; H-PTR ve L-PTR grupları arasında fark saptanmadı $(p>0,05)$. Multivariate lineer regresyon analizinde; baPWV bağımsız olarak; yaş $(p=0,001)$ ve $S B P(p=0,001)$ ile ilişkili saptandı ve $r G F R$ ve baPWV $(p=0,751)$ arasında ilişki saptanmadi.

Sonuç: H-PTR ve L-PTR grupları arasında AS gelişimi açısından fark saptanmadı. PD hastalarında rGFR, PTR ile AS arasında anlamlı ilişki saptanmadı.

Alındığı tarih: 25.09.2017

Kabul tarihi: 29.12 .2017

Yazışma adresi: Uzm. Dr. Ayça İnci, Antalya Eğitim ve Araştırma Hastanesi Nefroloji Kliniği,

Anahtar kelimeler: Periton, diyaliz, arteriyel, sertlik

Antalya - Türkiye

e-mail: aycainci2004@hotmail.com 


\section{INTRODUCTION}

Increased arterial stiffness (AS) is seen to be associated with increased cardiovascular (CV) mortality in patients with end-stage renal disease (ESRD) ${ }^{(1)}$. Pulse wave velocity (PWV) value is used to identify the AS that is used in the prediction of CV morbidity and mortality in patients with ESRD (2). PWV can be measured using systemic (aortic PWV), regional [brachial-ankle PWV (baPWV)] and local (radial PWV) methods. BaPWV is the preferred one among all these methods due to its easily applicability, practicality and reproducibility ${ }^{(3)}$.

While residual renal function (RRF) was sufficient in order to determine the adequacy of peritoneal dialysis (PD) previously ${ }^{(4)}$, the effect of peritoneal clearance was also demonstrated in the upcoming years. Szeto et al. ${ }^{(5)}$ reported that preservation of RRF had positive effects on CV morbidity and mortality. Wang et al. ${ }^{\left({ }^{6}\right)}$ reported that the incidence of $\mathrm{CV}$ complications increased with decreased RRF, secondary to increased hypervolemia. Lee et al. (7) reported an independent association between increased RRF and decreased AS in patients on PD. Contrary to all the studies stated above Chang et al. (8) reported lack of any association between RRF and AS in their study they had performed in PD patients.

One of the factors determining the adequacy of dialysis is the peritoneal transport rate (PTR) in PD treatment. The degree of PTR is defined by performing a peritoneal equilibration test (PET) which was developed by Twardowski et al. ${ }^{(9)}$. High peritoneal transport rate (H-PTR) and low peritoneal transport rate (L-PTR) is defined as 1 standard deviation higher and lower, than the mean dialysate/plasma creatinine values $(\mathrm{D} / \mathrm{P} \mathrm{Cr})$ at the end of a 4-hour evaluation, respectively. Patients with H-PTR have higher solute transport rates, and hence tend to have good urea and creatinine clearance rates ${ }^{(10)}$; however, ultrafiltration fails due to quick deterioration of osmotic pressure difference and thus hypervolemia develops. On the other hand, patients with L-PTR tend to have an altered urea and creatinine clearance, so uremic symptoms develop in time.

CV morbidity and mortality are known to increase in PD patients with H-PTR ${ }^{(11)}$ and decreased RRF. However, these associations have been shown in only a few studies and the results are still controversial. Based on these findings, the aim of this study was to determine the association between RRF and PTRs with AS determined by baPWV in PD patients.

\section{MATERIAL and METHODS}

\section{Patient selection}

Seventy-five patients on PD [44 men (58.7\%) / 31 women (41.3\%)] who were followed-up at the outpatient clinic of Antalya Training and Research Hospital between March 2014 and November 2016 were enrolled in this prospective and cross-sectional study. Fifty-six (74.6\%) patients were on CAPD consisting of two or three 2-L exchanges daily and $19(25.3 \%)$ patients were on APD consisting of three or four 5-L exchanges nightly, with standard dextrose-based dialysate solution. Twenty patients were excluded from the study due to uncontrolled hypertension, active infectious or inflammatory diseases and peritonitis within the last three months. Patients treated for $>3$ months prior to enrollment, cases with clinical stability without that did not experience attacks of peritonitis within the previous 3 months prior to enrollment were included in the study. Demographics and clinical data of the patients such as age, and gender of the patients, presence of primary renal disease and duration of PD were recorded. Blood pressure was measured twice, 10 minutes apart after a 15-minute rest period with the patient in the the supine position and the average of two measurements was recorded as the baseline systolic and diastolic blood pressures. Informed consent was obtained from each patient after the study was explained to them in detail. Ethics Board approval was obtained from the Ethics Committee of Antalya Training and Research Hospital. 


\section{Peritoneal Equilibration Test}

We used the standard PET (Peritoneal Equilibration Test) as described by Twardowski et al. ${ }^{(9)}$. PD exchange was applied as usual, in other words, the night before the application of PET in order that the dialysate stayed in the abdomen of the patient during the night. All the liquid in the abdomen of the patient was drained in the morning. Two liters of $2.27 \%$ dialysate solution was introduced into the abdomen of the patient lying in supine position. Time was recorded as 0 at the termination of the infusion. Concentrations of dialysate and plasma creatinine and dialysate glucose were measured 0,2 , and 4 hours. Dialysate glucose measured at 2 and 4 hours was proportioned to the dialysate glucose (D/Do) at hour 0 and dialysate creatinine was proportioned to plasma creatinine (D/P Cr). According to the results in charts, the patients were divided into four groups: high $(\mathrm{H})$, high-average (HA), low-average (LA) and low (L) peritoneal transport rate (PTR). D/P Cr values were determined to be greater than 0.80 for H-PTR, 0.65 to 0.80 for HA-PTR, 0.55 to 0.64 for LA-PTR and less than 0.5 for L-PTR. In this study, H-HA transporters were considered as H-PTR, whereas L-LA transporters as L-PTR.

\section{Adequacy of Dialysis}

Blood, urine and dialysate samples were collected for 24 hours in order to calculate urea clearance, weekly total $\mathrm{kt} /$ Vurea and weekly total creatinine clearance rates $(\mathrm{CCr})$. Total kt/Vurea was determined as the total loss of urea nitrogen in the exchanged dialysate using the Watson equation ${ }^{(12)}$. Total Ccr was calculated as the sum of peritoneal and renal Ccr. The residual clearance of the kidneys was also considered. The residual glomerular filtration rate (GFR) was calculated as the average of 24-hour urinary urea and creatinine clearance values ${ }^{(13)}$.

\section{Brachial-ankle Pulse Wave Velocity}

Brachial-ankle pulse wave velocity (baPWV) is a simple, non-invasive and reproducible method to determine arterial stiffness (AL). BaPWV was mea- sured in each patient after a 5-min rest in supine position in a quiet room. Patients were forbidden to consume caffeine and smoke cigarettes within a period of 3 hours prior to the measurement. BaPW which is an index of brachial arterial stiffness was measured using an automated computerized recorder ${ }^{(14)}$. PWV was calculated using a formula and the pulse transit time and the distance $(\mathrm{D} 1-\mathrm{D} 2)(\mathrm{PWV}(\mathrm{m} / \mathrm{s})=$ distance $(\mathrm{m}) /$ transit time (s)). Where D1 was the distance between heart and ankle and D2 between heart and arm. Pulse transit time was the transit time between the brachial and tibial arterial waves.

\section{Statistical Analysis}

Statistical analysis was performed using SPSS for Windows, version 18.0. Mean, standard deviation, min-max, median and frequency values were used to define the sample frequency distribution. The correlations between continuous variables were analyzed using Pearson and Spearman correlation tests. The Kappa test was used for compliance analysis. Independent samples t-test and Mann-Whitney U tests were used to determine the differences between independent groups. Multiple linear regression and logistic regression analysis were used to determine statistically significant independent variables that explain the variation in the baPWV, rGFR and PTRs. Level of significance was accepted as $p<0.05$.

\section{RESULTS}

The mean age of the patients was $53.7 \pm 13.3$ years and $44(58.7 \%)$ of the patients were males. Mean duration of PD was $41.5 \pm 31.9$ months. Mean SBP and DBP values were $123.7 \pm 21.0 \mathrm{mmHg}$ and $73.9 \pm 13.6$ $\mathrm{mmHg}$, respectively. Among 75 patients on PD, 56 (74.6\%) were treated by CAPD and the remaining 19 (25.4\%) by APD. Causes of renal failure were diabetic nephropathy in $22(29.3 \%)$, hypertensive nephrosclerosis in $36(48 \%)$, glomerulonephritis in 6 $(8.0 \%)$, polycystic renal disease in $3(4.0 \%)$, nephrolithiasis in $1(1.3 \%)$, and other conditions in 7 (9.3\%) patients. Hypertensive patients used angiotensin-con- 
verting enzyme inhibitors or angiotensin-II receptor blockers $(57.4 \%)$, calcium channel blockers $(24 \%)$, beta-receptor blockers $(16 \%)$, and other antihypertensive drugs $(2.6 \%)$.

Sixty-two $(82.7 \%)$ patients had daily residual urine output of $\geq 100 \mathrm{ml} /$ day. Mean daily urine output was $667 \pm 572 \mathrm{ml} /$ day and mean rGFR was $3.59 \pm 3.67 \mathrm{~L} /$ $\min / 1.73 \mathrm{~m}^{2}$. Weekly total kt/Vurea, residual kt/ Vurea and peritoneal $\mathrm{kt} /$ Vurea ratios were $2.37 \pm 0.60$, $0.72 \pm 0.62$ and $1.8 \pm 0.5$, respectively. Weekly total $\mathrm{CCr}$, peritoneal $\mathrm{CCr}$ and residual $\mathrm{CCr}$ were $87.28 \pm 38.63,39.47 \pm 42.23$ and $52.4 \pm 16.8 \mathrm{~L} / 1.73 \mathrm{~m}^{2}$, respectively. Mean D/P Cr was 0.68 \pm 0.14 . (High/ High-Average) H/HA was considered as H-PTR and

Table 1. Demographic characteristics, PETs findings and RRF, baPWV values of patients.

\begin{tabular}{|c|c|c|}
\hline Variable & Mean \pm SD $/ \%$ & Med (min-max) \\
\hline Age (years) & $53.7 \pm 13.3$ & $56(22-79)$ \\
\hline Male/Female & $44(58.7 \%) / 31(41.3 \%)$ & \\
\hline PD duration (months) & $41.5 \pm 31.9$ & $35(3-132)$ \\
\hline SBP/DBP (mmHg) & $123.7 \pm 21.0 / 73.9 \pm 13.6$ & $130(80-177) / 82(41-119)$ \\
\hline \multicolumn{3}{|l|}{ Etiology of renal failure } \\
\hline Diabetic nephropathy & $22(29.3 \%)$ & \\
\hline Hypertensive nephrosclerosis & $36(48 \%)$ & \\
\hline Glomerulonephritis & $6(8.0 \%)$ & \\
\hline Polycystic renal disease & $3(4.0 \%)$ & \\
\hline Nephrolithiasis & $1(1.3 \%)$ & \\
\hline Others & $7(9.3 \%)$ & \\
\hline \multicolumn{3}{|l|}{ Use of antihipertansif drugs } \\
\hline $\mathrm{ACE}$ inh/ARB & $43(57.4 \%)$ & \\
\hline Ca-channel blokers & $18(24 \%)$ & \\
\hline Beta-blokers & $12(16 \%)$ & \\
\hline Others & $2(2.6 \%)$ & \\
\hline RRF (ml/day) & $667 \pm 572$ & \\
\hline Residual urine output ( $\geq 100 \mathrm{ml} /$ day) & $62(82.7 \%)$ & \\
\hline $\operatorname{rGFR}\left(\mathrm{L} / \mathrm{min} / 1.73 \mathrm{~m}^{2}\right)$ & $3.59 \pm 3.67$ & $2.36(0.10-19.32)$ \\
\hline Weekly total kt/Vurea & $2.37 \pm 0.60$ & $2.34(1.33-4.41)$ \\
\hline Residual kt/Vurea & $0.72 \pm 0.62$ & $0.62(0.10-2.92)$ \\
\hline Peritoneal kt/Vurea & $1.8 \pm 0.5$ & $1.7(0.3-3.0)$ \\
\hline Weekly total CCr (L/week) & $87.28 \pm 38.63$ & $74.28(25.02-245.42)$ \\
\hline Residual CCr (L/1.73 m²) & $39.47 \pm 42.23$ & $25.47(0.80-192.84)$ \\
\hline Peritoneal CCr $\left(\mathrm{L} / 1.73 \mathrm{~m}^{2}\right)$ & $52.4 \pm 16.8$ & $51.3(21.4-120.3)$ \\
\hline PD modality (CAPD/APD) & $56(74.6 \%) / 19(25.3 \%)$ & \\
\hline H-HA/L-LA PTRs & $48(64 \%) / 27(36 \%)$ & \\
\hline $\mathrm{D} / \mathrm{PCr}$ & $0.68 \pm 0.14$ & $0.68(0.21-0.98)$ \\
\hline baPWV (m/sec) & $8.1 \pm 1.8$ & $8.0(4.9-13.4)$ \\
\hline
\end{tabular}

Data are presented as mean \pm standart deviation. Abbreviations $=S B P=$ Systolic blood pressure; DBP=Diastolic BP; RRF $=$ Residual renal function;

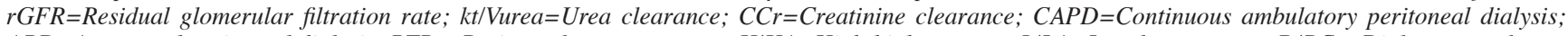
$A P D=$ Automated peritoneal dialysis; $P T R s=P e r i t o n e a l ~ t r a n s p o r t ~ r a t e s ; ~ H / H A=H i g h$-high average; $L / L A=L o w$-low average $; D / P C r=D i a l y s a t e-t o-p l a s m a$ ratio of creatinine; baPWV=Brachial-ankle pulse wave velocity.

Table 2. Comparison PET's findings between high and low baPWV group patients.

\begin{tabular}{|c|c|c|c|}
\hline & $\begin{array}{c}\text { baPWV } \leq 8.0(\mathrm{~m} / \mathrm{sec}) \\
\text { Mean } \pm \mathrm{SD} / \%\end{array}$ & $\begin{array}{c}\text { baPWV }>8.0(\mathrm{~m} / \mathrm{sec}) \\
\text { Mean } \pm \mathrm{SD} / \%\end{array}$ & $\mathbf{p}$ \\
\hline Age (years) & $48.24 \pm 12.84$ & $59.27 \pm 11.53$ & 0.000 \\
\hline Male/Female & $20(52.6 \%) / 18(47.4 \%)$ & $24(64.9 \%) / 13(35.1 \%)$ & 0.282 \\
\hline PD duration (months) & $40 \pm 33$ & $43 \pm 31$ & 0.442 \\
\hline $\mathrm{SBP}(\mathrm{mmHg})$ & $121.53 \pm 20.51$ & $139.49 \pm 23.14$ & 0.000 \\
\hline $\mathrm{DBP}(\mathrm{mmHg})$ & $77.42 \pm 17.17$ & $83.16 \pm 16.48$ & 0.171 \\
\hline $\mathrm{rGFR}\left(\mathrm{L} / \mathrm{min} / 1.73 \mathrm{~m}^{2}\right)$ & $4.24 \pm 4.61$ & $3.51 \pm 4.43$ & 0.610 \\
\hline Residual kt/Vurea & $0.59 \pm 0.65$ & $0.47 \pm 0.59$ & 0.444 \\
\hline Peritoneal kt/Vurea & $1.80 \pm 0.61$ & $1.82 \pm 0.48$ & 0.759 \\
\hline Residual CCr (L/1.73 m²) & $33.52 \pm 41.42$ & $31.35 \pm 40.75$ & 0.962 \\
\hline Peritoneal CC r $\left(\mathrm{L} / 1.73 \mathrm{~m}^{2}\right)$ & $51.32 \pm 16.04$ & $53.48 \pm 17.71$ & 0.849 \\
\hline CAPD/APD & $24(63.2 \%) / 14(36.8 \%)$ & $32(86.5 \%) / 5(13.5 \%)$ & 0.020 \\
\hline H-HA/L-LA PTRs & $26(68.42 \%) / 12(31.58 \%)$ & $22(59.46 \%) / 15(40.54 \%)$ & 0.419 \\
\hline
\end{tabular}

Mann-Withney-U test, Pearson Chi Square, Fisher's Exact test 
L/LA was considered as L PTR. Forty-eight (64\%) patients were in H-PTR and 27 (36\%) in L-PTR groups. Mean baPWV value was $8.1 \pm 1.8 \mathrm{~m} / \mathrm{sec}$ (Table 1). Patients were divided into two subgroups according to the median baPWV value. Older age $(\mathrm{p}=0.000)$, SBP $(\mathrm{p}=0.000)$ and PD modality $(\mathrm{p}=0.020)$ were statistically significantly different between the high and low baPWV groups. Gender, duration of PD, DBP, PTRs, D/P Cr, rGFR, residual kt/Vurea, peritoneal kt/ Vurea, residual $\mathrm{CCr}$ and peritoneal $\mathrm{CCr}$ were similar between patients with a low baPWV and high baPWV ( $\mathrm{p}>0.005)$ (Table 2).

Patients were divided into two subgroups according to their median rGFR values: Patients with a median rGFR above $2.36 \mathrm{~mL} / \mathrm{min} / 1.73 \mathrm{~m}^{2}$ were grouped as the high group $(\mathrm{n}=48)$, while those with a median rGFR below $2.36 \mathrm{~mL} / \mathrm{min} / 1.73 \mathrm{~m}^{2}$ as the anuric group $(\mathrm{n}=27)$. Duration of $\mathrm{PD}$ was significantly low in rGFR $>2.36 \mathrm{~mL} / \mathrm{min} / 1.73 \mathrm{~m}^{2}$ group compared to the group of patients with a rGFR $\leq 2.36 \mathrm{~mL} /$

Table 3. Comparison of patients characteristics according to median rGFR values.

\begin{tabular}{|c|c|c|c|}
\hline & $\begin{array}{c}\text { rGFR } \leq 2.36 \mathrm{~mL} / \mathrm{min} / 1.73 \mathrm{~m}^{2} \\
(\mathrm{n}=39) \\
\text { Mean } \pm \text { S.D./n-\%.Me }(\min -\mathrm{max})\end{array}$ & $\begin{array}{c}\text { rGFR }>2.36 \mathrm{~mL} / \mathrm{min} / 1.73 \mathrm{~m}^{2} \\
(\mathrm{n}=36) \\
\text { Mean } \pm \text { S.D./n-\%. Med (min-max })\end{array}$ & $\mathbf{p}$ \\
\hline Age (years) & $51.33 \pm 14.04 / 54(23-77)$ & $56.22 \pm 12.22$ / 57 (22-79) & 0.168 \\
\hline Male/Female & $20(51.3 \%) / 19(48.7 \%)$ & $24(66.7 \%) / 12(33.3 \%)$ & 0.162 \\
\hline PD duration (months) & $48 \pm 33$ / $38(4-132)$ & $34 \pm 29 / 25(3-95)$ & 0.042 \\
\hline $\mathrm{SBP}(\mathrm{mmHg})$ & $130.87 \pm 27.80 / 135(80-177)$ & $129.86 \pm 18.12 / 130(84-161)$ & 0.63 \\
\hline $\mathrm{DBP}(\mathrm{mmHg})$ & $81.28 \pm 19.98 / 82(41-119)$ & $79.14 \pm 13.15 / 82(41-102)$ & 0.55 \\
\hline $\mathrm{CAPD} / \mathrm{APD}$ & $31(79.5 \%) / 8(20.5 \%)$ & $25(69.4 \%) / 11(30.6 \%)$ & 0.321 \\
\hline H-HA/L-LA PTRs & $25(64.1 \%) / 14(35.9 \%)$ & $23(63.9 \%) / 13(36.1 \%)$ & 0.978 \\
\hline $\mathrm{baPWV}(\mathrm{m} / \mathrm{sec})$ & $8.17 \pm 1.97 / 8.1(4.9-12.5)$ & $7.94 \pm 1.69 / 7.85(5.7-13.4)$ & 0.509 \\
\hline
\end{tabular}

Mann-Withney-U test, Pearson Chi Square, Fisher's Exact test

Table 4. Comparison of patients' characteristics according to PTRs types.

\begin{tabular}{lccc}
\hline & $\begin{array}{c}\text { H-HA PTRs (n=48) } \\
\text { Mean } \pm \text { S.D./n-\%.Med (min-max) }\end{array}$ & $\begin{array}{c}\text { L-LA PTRs (n=27) } \\
\text { Mean } \pm \text { S.D./n-\%. Med (min-max) }\end{array}$ & p \\
\hline Age (years) & $53.2 \pm 14 / 58(22-79)$ & $53.4 \pm 14.2 / 54(23-77)$ & 0.959 \\
Male/Female & $29(38.6 \%) / 19(25.3 \%)$ & $15(20 \%) / 12(16 \%)$ & 0.485 \\
PD duration (months) & $40.2 \pm 30.4 / 31(3-106)$ & $49.7 \pm 32.8 / 39(13-132)$ & 0.234 \\
SBP (mmHg) & $126 \pm 20.4 / 125(70-170)$ & $119.6 \pm 20.5 / 120(80-150)$ & 0.219 \\
DBP (mmHg) & $76 \pm 14.8 / 80(40-110)$ & $71.5 \pm 10.5 / 70(50-90)$ & 0.187 \\
rGFR (L/min/1.73 m $\left.{ }^{2}\right)$ & $3.66 \pm 4.04 / 1.91(0.00-19.32)$ & $4.27 \pm 5.3 / 2.35(0.0-20.3)$ & 0.956 \\
CAPD/APD & $36(75 \%) / 12(25 \%)$ & $20(74.1 \%) / 7(25.9 \%)$ & 0.929 \\
baPWV (m/sec) & $8.0 \pm 1.8 / 7.9(4.9-13.4)$ & $8.2 \pm 2.0 / 8.1(5.3-12.5)$ & 0.611 \\
& & & \\
\hline
\end{tabular}

Independent-sample t test, Mann-Whitney U test

Table 5. Independent variables affecting of baPWV.

\begin{tabular}{|c|c|c|c|}
\hline Variables & Standard $\beta$ & Partial Correlations & $\mathbf{p}$ \\
\hline Age (years) & 0.733 & 9.101 & 0.001 \\
\hline PD duration (months) & 0.073 & 0,911 & 0.366 \\
\hline $\mathrm{SBP}(\mathrm{mmHg})$ & 0.519 & 6.597 & 0.001 \\
\hline $\mathrm{DBP}(\mathrm{mmHg})$ & 0.007 & 0.067 & 0.947 \\
\hline $\mathrm{rGFR}\left(\mathrm{L} / \mathrm{min} / 1.73 \mathrm{~m}^{2}\right)$ & 0.004 & 0.083 & 0.934 \\
\hline Residual kt/Vurea & 0.206 & 0.600 & 0.551 \\
\hline Peritoneal kt/Vurea & 0.010 & 0.122 & 0.903 \\
\hline Residual CCr $\left(\mathrm{L} / 1.73 \mathrm{~m}^{2}\right)$ & 0.004 & 0.718 & 0.475 \\
\hline Peritoneal CCr $\left(\mathrm{L} / 1.73 \mathrm{~m}^{2}\right)$ & 0.068 & 0.870 & 0.388 \\
\hline PD modality & -0.943 & -1.979 & 0.052 \\
\hline H-HA/L-LÄ PTRs & 0.060 & 0.527 & 0.600 \\
\hline
\end{tabular}

Linear regression 
Table 6. Independent variables affecting of rGFR.

\begin{tabular}{lccc}
\hline Variables & Standard $\boldsymbol{\beta}$ & Partial Correlations & $\mathbf{p}$ \\
\hline Age (years) & 0.112 & 1.026 & 0.308 \\
PD duration (months) & -0.141 & -1.328 & 0.188 \\
SBP (mmHg) & 0.056 & 0.522 & 0.603 \\
DBP (mmHg) & -0.044 & -0.408 & 0.685 \\
PD modality & 0.420 & 0.349 & 0.728 \\
H-HA/L-LA PTRs & 0.605 & 0.555 & 0.580 \\
baPWV (m/sec) & -0.034 & -0.318 & 0.751 \\
\end{tabular}

Linear regression

Table 7. Independent variables affecting of PTRs.

\begin{tabular}{lccc}
\hline Variables & Standard $\boldsymbol{\beta}$ & $\mathbf{p}$ & Odds ratio \\
\hline Age (years) & 0.009 & 0.702 & 1.009 \\
PD duration (months) & -0.049 & 0.929 & 0.952 \\
SBP $(\mathrm{mmHg})$ & -0.002 & 0.849 & 0.998 \\
DBP (mmHg) & -0.011 & 0.427 & 0.989 \\
rGFR (L/min/1.73 m $\left.{ }^{2}\right)$ & 0.030 & 0.576 & 1.030 \\
PD modality & -0.049 & 0.929 & 0.952 \\
baPWV (m/sec) & 0.077 & 0.559 & 1.080 \\
& & & \\
\hline
\end{tabular}

Multivariate Logistic Regression

$\mathrm{min} / 1.73 \mathrm{~m}^{2}(\mathrm{p}=0.042) . \operatorname{SBP}(\mathrm{p}=0.63), \operatorname{DBP}(\mathrm{p}=0,55)$, PD modalilty $(\mathrm{p}=0.321)$, PTRs $(\mathrm{p}=0.978)$ and baPWV $(\mathrm{p}=0.509)$ were similar in two groups (Table 3). Age $(p=0.959)$, and gender of the patients $(p=0.485)$, duration of PD ( $\mathrm{p}=0.234), \operatorname{SBP}(\mathrm{p}=0.219), \operatorname{DBP}(\mathrm{p}=0.187)$, rGFR ( $\mathrm{p}=0.956)$, PD modality $(\mathrm{p}=0.929)$ and baPWV $(\mathrm{p}=0.611)$ were comparable in H-PTRs and L-PTRs groups (Table 4).

In multivariate linear regression analysis; baPWV was independently associated with age $(\beta=0.733$, $\mathrm{p}=0.001)$ and $\operatorname{SBP}(\beta=0.519, \mathrm{p}=0.001)$ (Table 5). No independent association was found between rGFR and age $(\beta=0.112, p=0.308)$, duration of PD $(\beta=0.141$, $\mathrm{p}=0.188), \operatorname{SBP}(\beta=0.056, \mathrm{p}=0.603), \mathrm{DBP}(\beta=-0.044$, $\mathrm{p}=0.685)$, PD modality $(\beta=0.420, \mathrm{p}=0.728)$, PTRs $(\beta=0.605, p=0.580)$ and baPWV $(\beta=-0.034, p=0751)$ in multivariate linear regression analysis (Table 6). No independent association was found between PTRs and age of the patients $(\beta=0.009, p=0.702)$, duration of PD $(\beta=-0.049, p=0.929), \operatorname{SBP}(\beta=-0.002, p=0.849), \mathrm{DBP}$ $\beta=-0.011, p=0.427)$, rGFR $(\beta=0.030, p=0.576), P D$ modality $(\beta=-0.049, \mathrm{p}=0.929)$ and baPWV $(\beta=0.077$, $\mathrm{p}=0.559)$ in multivariate logistic regression analysis (Table 7).

\section{DISCUSSION}

Vascular elasticity prevents damage to the circulation due to high pressure. Loss of elasticity of the vascular wall, advanced age, diabetes, atherosclerosis, inflammation, genetic factors and cigarette smoking are factors that cause the development of AS. PD carries a high risk in terms of increased rate of AS and CV mortality ${ }^{(15)}$. Elevated AS results in an increase in CV mortality by causing an increased systolic blood pressure, left ventricular hypertrophy and decreased coronary perfusion ${ }^{(16)}$. PWV can be measured on many sites using various instruments and methods ${ }^{(17)}$. Among those, baPWV is a widely used method since it is easily applied, cheap and noninvasive ${ }^{(3)}$.

RRF is related to all-cause mortality (18) and decreased RRF is associated with increased mortality and CV disease in PD patients ${ }^{(19)}$. Developing hypervolemia due to decreased RRF causes AS because of arterial distension ${ }^{(20)}$. CANUSA study demonstrated that survival in patients on PD was affected by the presence of RRF ${ }^{(21)}$. Caliskan et al. ${ }^{(22)}$ in their study on PD patients reported that the risk of development of AS increased with a decreased RRF. Huang et al. 
${ }^{(23)}$ showed an independent inverse correlation between RRF and AS determined by baPWV. Mimura et al. ${ }^{(24)}$ reported that development of AS was seen rarely in PD patients due to a more preserved RRF. In contrast to these studies, Chang et al. ${ }^{(8)}$ found no significant association between development of AS and presence of RRF in PD patients. In the present study, baPWV was similar in both the low rGFR and high rGFR groups of patients. There was no independent association between rGFR, residual kt/Vurea, residual $\mathrm{CCr}$ and AS in multivariate analysis. These discrepancies between studies may be explained by different characteristics of the study populations such as demographic characteristics, compliance to salt-free diet, volume status and blood pressure of the patients. In addition, no statistically significant difference in blood pressure levels was observed between low rGFR and high rGFR groups, although increased blood pressure is known to be a cause of increased AS. This situation suggests that there was no protective effect of the presence of RRF on the development of AS.

It is easy to achieve the goals of dialysis in patients with H-PTR; however, hypervolemia develops due to inefficient ultrafiltration. It is hard to achieve the desired level of adequate volemic status in patients with L-PTR, especially in those without RRF. H-PTR is considered to be associated with increased CV morbidity and mortality. The result of studies investigating the associations between PTRs and increased AS are conflicting. Wang et al. (25) reported an independent association between H-PTR and increased AS in patients on PD. Huang et al. ${ }^{(23)}$ reported lack of anny correlation between PTRs and baPWV. Gao et al. (26) also reported absence of any association between PTRs and increased AS. In this present study, no association between PTRs and baPWV was demonstrated as was the case in a previously published study ${ }^{(27)}$. The differences between the studies may originate from the differences in the demographics of the patients and the limited number of subjects in this present study.

This present study has several limitations. First, patients were under some concurrent medications which were not changed during the study for ethical considerations. Thus, this might have influenced the accuracy of the measurements. In addition, this was a cross-sectional study with a relatively small sample size. Third, no healthy volunteering control group was used in the study for comparisons. Fourthly, no evaluation of the effect of the developing changes in the peritoneal permeability and residual renal functions of the patients on the development of arterial stiffness in time was performed since the study was cross-sectional and performed within a single time period.

\section{CONCLUSION}

Advanced age and increased blood pressure are known to be the most important factors leading to the development of AS ${ }^{(28)}$. No difference was found in the development of AS in terms of the presence/ absence of RRF and PTRs types and this might be due to the similarity of the groups in terms of age and blood pressure variables. However, future multicenter studies on a large number of patients are needed in order to determine the effects of malnutrition, inflammation and hypervolemia, levels of serum albumin ${ }^{(29)}$ and lipid, high sensitive C-reactive protein ${ }^{(30)}$ and fluid excess on CV mortality.

Conflict of interest: The authors declare that they have no conflict of interest.

\section{REFERENCES}

1. Blacher J, Guerin AP, Pannier B, Marchais SJ, London GM. Arterial calcifi cations, arterial stiffness, and cardiovascular risk in end-stage renal disease. Hypertension. 2001;38:93842.

https://doi.org/10.1161/hy1001.096358

2. Guerin AP, Blacher J, Pannier B, Marchais SJ, Safar ME, London GM. Impact of aortic stiffness attenuation on survival of patients in end-stage renal failure. Circulation. 2001;103:987-92. https://doi.org/10.1161/01.CIR.103.7.987

3. Yamashina A, Tomiyama H, Takeda K, Tsuda H, Arai T, Hirose K, Koji Y, Hori S, Yamamoto Y. Validity, reproducibility, and clinical significance of noninvasive brachial-ankle pulse wave velocity measurement. Hypertens Res. 2002;25(3):359-64. 
https://doi.org/10.1291/hypres.25.359

4. Maiorca R, Brunori G, Zubani R, et al. Predictive value of dialysis adequacy and nutritional indices for mortality and morbidity in CAPD and HD patients. A longitudinal study. Nephrol Dial Transplant. 1995;10:2295-2305. https://doi.org/10.1093/ndt/10.12.2295

5. Szeto CC, Wong TY, Chow KM, Leung CB, Li PK. Are peritoneal dialysis patients with and without residual renal function equivalent for survival study? Insight from a retrospective review of the cause of death. Nephrol Dial Transplant. 2003;18:977-82. https://doi.org/10.1093/ndt/gfg027

6. Wang AY, Wang M, Woo J, Law MC, Chow KM, Li PK, Lui SF, Sanderson JE. A novel association between residual renal function and left ventricular hypertrophy in peritoneal dialysis patients. Kidney Int. 2002;62:639-47. https://doi.org/10.1046/j.1523-1755.2002.00471.x

7. Lee CT, Tsai YC, Su CY, et al. Interleukin 10 and residual kidney function are associated with risk of vascular calcifi cation in patients undergoing peritoneal dialysis. Clin Nephrol. 2011;75:397-402.

https://doi.org/10.5414/CNP75397

8. Chang JH, Yoon SJ, Han SH, Shin SK, Jeon DW, Yang JY, Kang EW. The impact of dialysis modality on arterial stiffness in patients with end-stage renal disease. Ren Fail. 2010;32(8):947-53. https://doi.org/10.3109/0886022X.2010.502607

9. Twardowski ZJ, Nolph KD, Prowant B, Ryan L, Moore H, Nielsen MP. Peritoneal equilibration test. Perit Dial Bull 1987;7:138-47.

10. Cueto-Manzano AM. Rapid solute transport in the peritoneum: physiologic and clinical consequences. Perit Dial Int. 2009;29(Suppl 2):90-5.

11. T Wang, O Heimbürger, J Waniewski, J Bergström, B Lindholm. Increased peritoneal permeability is associated with decreased fluid and small-solute removal and higher mortality in CAPD patients. Nephrol Dial Transplant. 1998;13(5):1242-9. https://doi.org/10.1093/ndt/13.5.1242

12. Floré KM, Delanghe JR. Analytical interferences in point-ofcare testing glucometers by icodextrin and its metabolites: an overview. Perit Dial Int. 2009;29(4):377-83.

13. van Olden RW, Krediet RT, Struijk DG, Arisz L. Measurement of residual renal function in patients treated with continuous ambulatory peritoneal dialysis. J Am Soc Nephrol. 1996;7(5):745-50.

14. Asmar R, Benetos A, Topouchian J, Laurent P, Pannier B, Brisac AM, Target R, Levy BI. Assessment of arterial distensibility by automatic pulse wave velocity measurement. Validation and clinical application studies. Hypertension. 1995;26:485-90. https://doi.org/10.1161/01.HYP.26.3.485

15. Wang AY. Cardiovascular risk factors in peritoneal dialysis patients revisited. Perit Dial Int. 2007;27(Suppl 2):223-7.

16. Demirci MS, Asci G, Kayikcioglu M, Ozkahya M, Ertilav M, Tanrisev M, Erten S, Ok E. Comparison of different arterial stiffness parameters on prediction of mortality in hemodialysis patients. American Society of Nephrology Renal Week. 2009; 1779.

17. Guerin AP, Blacher J, Pannier B, Marchais SJ, Safar ME, London GM. Impact of aortic stiffness attenuation on survival of patients in end-stage renal failure. Circulation. 2001;103(7):987-92.

https://doi.org/10.1161/01.CIR.103.7.987
18. Perl J, Bargman JM. The importance of residual kidney function for patients on dialysis: a critical review. Am J Kidney Dis. 2009;53(6):1068-81. https://doi.org/10.1053/j.ajkd.2009.02.012

19. Shemin D, Bostom AG, Lambert C, Hill C, Kitsen J, Kliger AS. Residual renal function in a large cohort of peritoneal dialysis patients: change over time, impact on mortalitynand nutrition. Perit Dial Int. 2000;20:439-44.

20. Barenbrock M, Spieker C, Laske V. Studies of the vessel wall properties in hemodialysis patients. Kidney Int. 1994;45(5):1397-1400. https://doi.org/10.1038/ki.1994.182

21. Bargman JM, Thorpe KE, Churchill DN. CANUSA Peritoneal Dialysis Study Group. Relative contribution of residual renal function and peritoneal clearance to adequacy of dialysis: a reanalysis of the CANUSA study. J Am Soc Nephrol. 2001;12(10):2158-62.

22. Caliskan Y, Ozkok A, Akagun T, Alpay N, Guz G, Polat N, Tufan F, Ecder T, Bozfakioglu S. Cardiac biomarkers and noninvasive predictors of atherosclerosis in chronic peritoneal dialysis patients. Kidney Blood Press Res. 2012;35(5):340-8. https://doi.org/10.1159/000332084

23. Huang WH, Chen KH, Hsu CW, Chen YC, Hung CC, Huang JY, Lin JL, Yang CW. Residual renal function - one of the factors associated with arterial stiffness in peritoneal dialysis patients. Insight from a retrospective study in 146 peritoneal dialysis patients. Blood Purif. 2008;26(2):133-7. https://doi.org/10.1159/000113013

24. Mimura T, Takenaka T, Kanno Y, Aoki H, Ohshima J, Suzuki $\mathrm{H}$. Comparison of changes in pulse wave velocity in patients on continuous ambulatory peritoneal dialysis and hemodialysis one year after introduction of dialysis therapy. Adv Perit Dial. 2005;21:139-45.

25. Zhe XW, Tian XK, Chen W, Guo LJ, Gu Y, Chen HM, Tang LJ, Wang T. Association between arterial stiffness and peritoneal small solute transport rate. Artif Organs. 2008;32(5):416-9. https://doi.org/10.1111/j.1525-1594.2008.00562.x

26. Gao N, Kwan BC, Chow KM, Chung KY, Pang WF, Leung $\mathrm{CB}$, Li PK, Szeto CC. Arterial pulse wave velocity and peritoneal transport characteristics independently predict hospitalization in Chinese peritoneal dialysis patients. Perit Dial Int. 2010;30(1):80-5. https://doi.org/10.3747/pdi.2008.00270

27. Figueiredo AE, Pinheiro da Costa BE, Conti A, Poitevin AA, Filho BJ, Torres E, d'Avila DO, Poli de Figueiredo CE. Peritoneal transport function and endothelium-dependent vasodilation. Perit Dial Int. 2007;27(2):203-5.

28. Haydar AA, Covic A, Colhoun H, Rubens M, Goldsmith DJ. Coronary artery calcification and aortic pulse wave velocity in chronic kidney disease patients. Kidney Int. 2004;65(5):1790-4. https://doi.org/10.1111/j.1523-1755.2004.00581.x

29. Adequacy of dialysis and nutrition in continuous peritoneal dialysis: association with clinical outcomes. CanadaUSA(CANUSA) Peritoneal Dialysis Study Group. J Am Soc Nephrol. 1996;7:198-207.

30. Stenvinkel P, Heimburger O, Paultre F, Diczfalusy U, Wang T, Berglund L, Jogestrand T. Strong association between malnutrition, inflammation, and atherosclerosis in chronic renal failure. Kidney Int. 1999;55:1899-911. https://doi.org/10.1046/j.1523-1755.1999.00422.x 